\title{
Seasonal Changes in the Water and Heleoplankton of Fresh-water Ponds.
}

By

W. R. G. Atkins and G. T. Harris.

Sci. Proc. Roy. Dublin Soc., 1924, 18, 1-21. Abstract with Figs. 1-3 by kind permission of the Publications Committee, Royal Dublin Society.

THE seasonal changes in the heleoplankton of two fresh-water ponds have been compared with alterations in the solutes, and it has been shown that in each there was a vernal rise in $\mathrm{pH}$ followed by a period of stagnation with lowered $\mathrm{pH}$. In the quarry pond of Borough Farm, Antony, this condition persisted till the autumn; in Staddon reservoir it was succeeded by a period of high alkalinity, lasting till October. These changes are associated with the spring increase in plankton, and the development of masses of floating algæ in Staddon reservoir ; they may be traced in Figs. 1 and 3.

The electrical conductivity, measured at $0^{\circ} \mathrm{C}$., is high when the $\mathrm{pH}$ value is low, and vice versa. The fall in conductivity is caused by the precipitation of carbonates of calcium and magnesium, owing to the reduction in the amount of carbonic acid in solution. The decrease in conductivity may, in part, be due to the removal by the algæ of electrolytes necessary for their growth. The $\mathrm{pH}$ values given here and their necessary effect upon the conductivity support Transeau's conclusions, based upon freezing point determinations, that the periods of heavy rainfall are the periods of greatest concentration in the solutes. Hodgetts, however, found that the reverse was the rule in the ponds he studied, but his figures for hardness and organic matter show that the latter predominated and the former was low. Accordingly the changes in electrolytes were masked. In both ponds the supply of phosphate is exhausted in spring, and this sets a limit to the further growth of the algæ. Staddon pond, however, has an inflow rich in phosphate, which permits of continued growth. The behaviour of this water source is shown in Fig. 2. Phosphate increases again in winter, partly by regeneration, but mainly by the inflow of water rich in phosphate. A comparison with analyses for the nitrogen compounds found in other ponds makes it highly probable 
that lack of phosphate rather than lack of nitrate or ammonium salts limits the plankton as a general rule in fresh water, as it does in the sea.

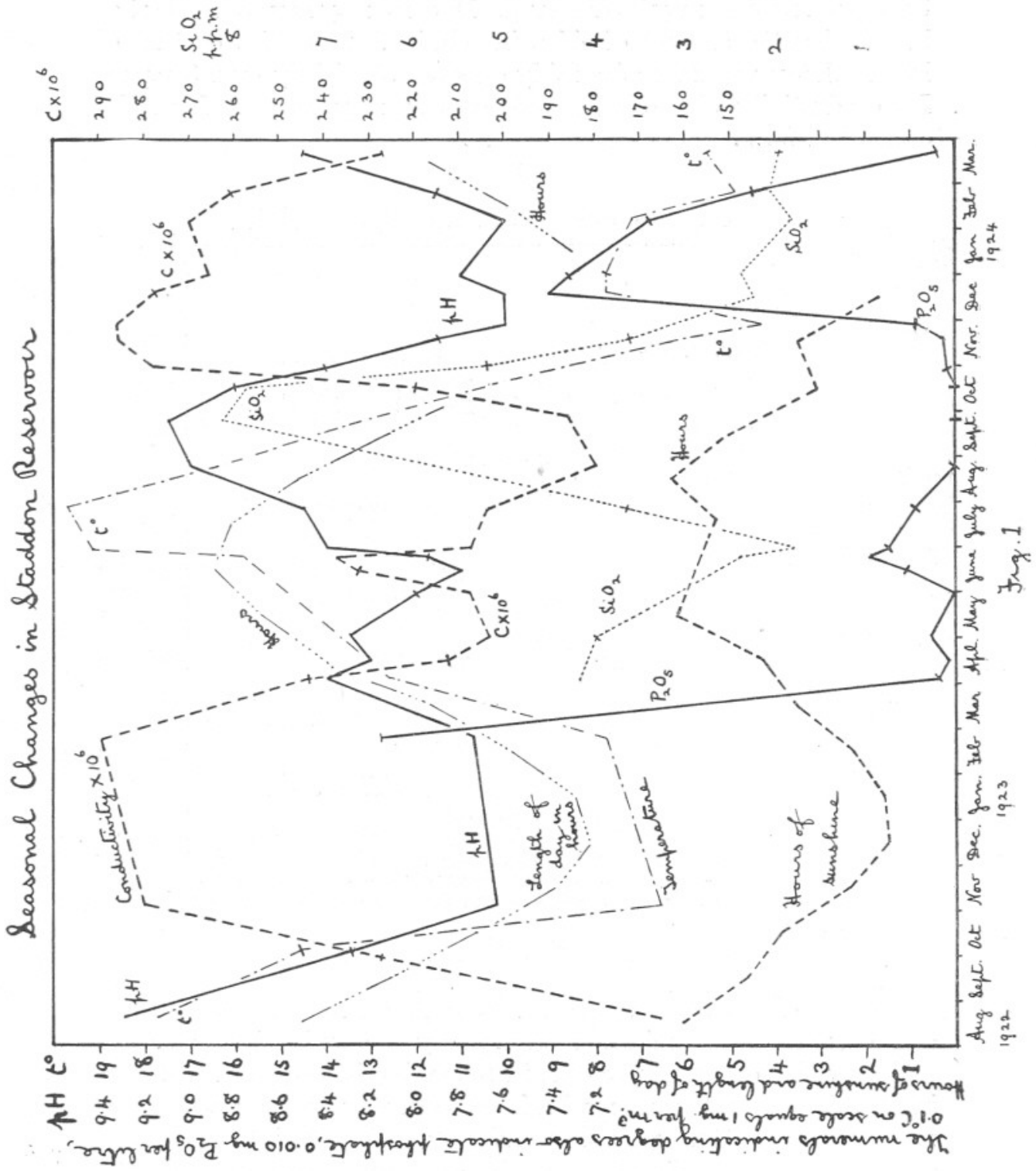

The data given by Pearsall and by Drew are of interest as regards the concentrations of nitrogenous compounds found in fresh water.

The silica content of the two ponds differed considerably, that on the Staddon grits being richer than that on the Upper Devonian slates. 
The seasonal changes are complex, but it appears that if turbidity due to particles of clay coincides with a high $\mathrm{pH}$ value much silica, up to 8 parts per million, may be dissolved. Diatoms may have a small effect in reducing the amount of silica in solution. The silica content of Plymouth tap water remains fairly constant at slightly over 3 p.p.m. Its conductivity also changes but little as may be seen from the curves in Fig. 2.

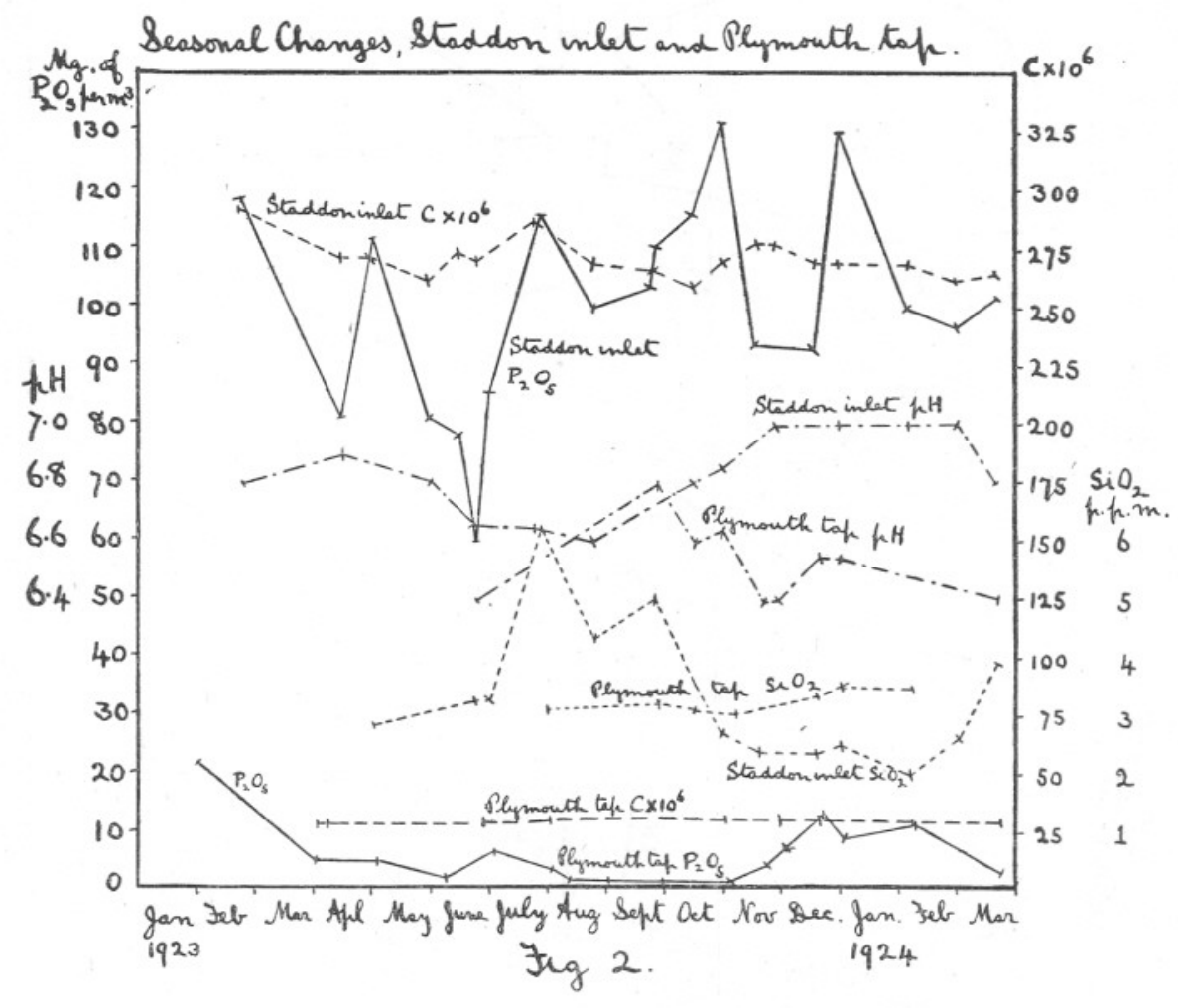

The tint of the water was found to undergo more or less irregular changes, partly due to mineral matter, partly to organic substances.

The rapid increase in plankton in the spring is associated with the increase in light rather than with increase in temperature; the latter may even fall while the $\mathrm{pH}$ value continues to rise. The warming of the surface in summer tends to lessen mixing of the water, and so contributes towards stagnation. Figs. 1 and 3 include graphs showing the temperature of the water, the mean length of the day for each month and the monthly mean of the daily sunshine records.

It may be concluded from other work that oxygen is present to satura- 
tion point when the $\mathrm{pH}$ value is about $8 \cdot 1$ in hard water, but is much reduced when the alkalinity falls to $\mathrm{pH} 7 \cdot 2$.

Ponds studied have ranged from $\mathrm{pH} 5 \cdot 0$ on Dartmoor to $\mathrm{pH} 9 \cdot 4$ for

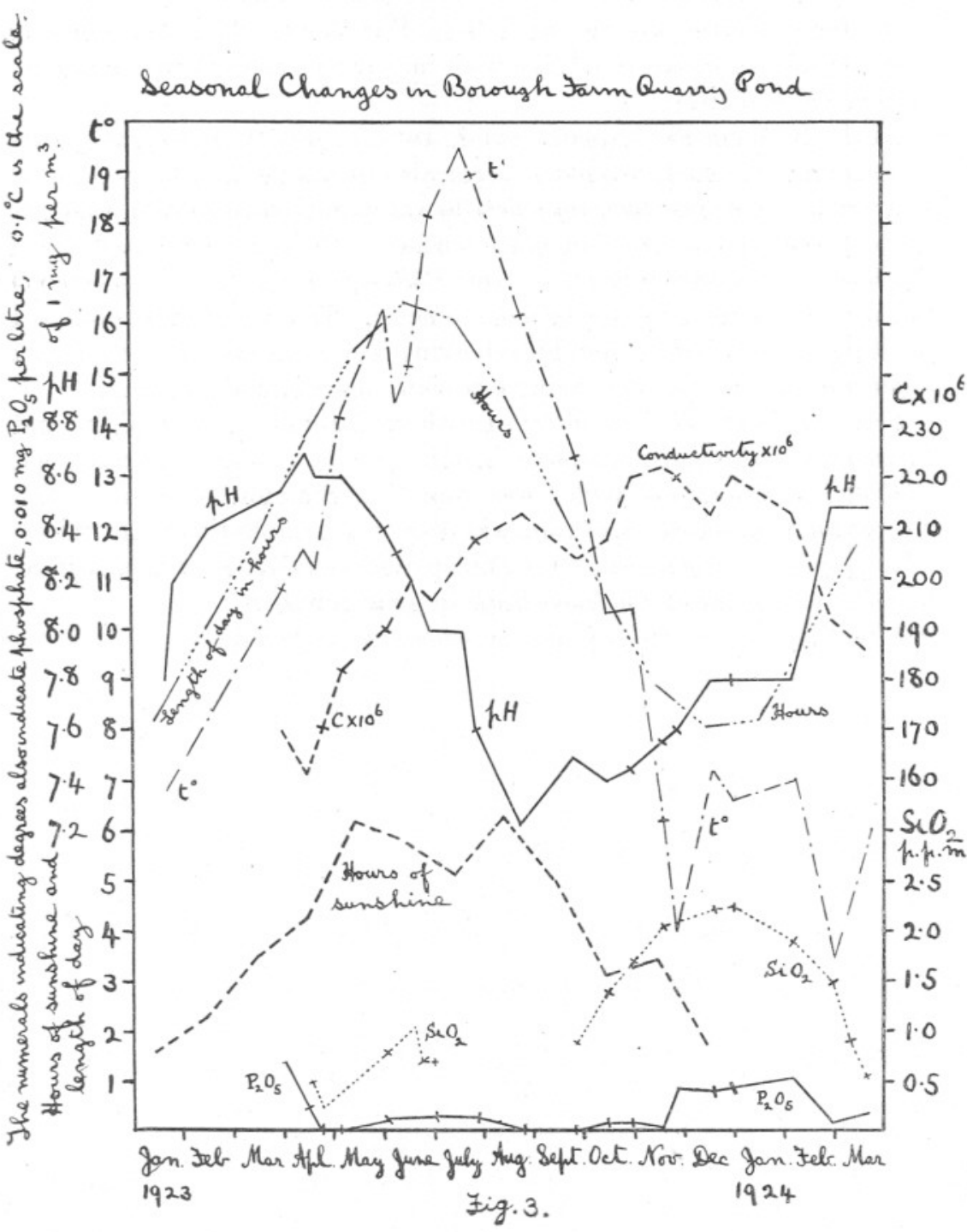

hard water ponds with abundant plankton. The electrical conductivity of natural fresh waters was found to vary from $\mathrm{C} \times 10^{6}=19$ to 270 , or even 300 , at $0^{\circ} \mathrm{C}$.

In the Staddon pond Tetraedron minimum was usually dominant, and 
occurred in nearly pure growth; as many as 8000 per c.c. were found in May. Microcystis aeruginosa was very abundant in August, 1923, T. minimum having disappeared. In October and November, 1923, the latter and Spharella lacustris were abundant. Ninety species of algæ, including varieties, are recorded from this pond. The occurrence of seven species is shown in a table with indications as to their abundance during 1922 to 1924 .

In the Borough Farm quarry pond, Antony, only twenty-eight species were found, of which seventeen occur also in Staddon. The pond is at times rich in diatoms; Synedra pulchella was found late in April in amounts up to 32,000 per c.c. A scum on the surface at the same period contained Euglena viridis 46,000 per c.c., and Chlamydomonas globosa $5,800,000$ per c.c., as counted by the hæmocytometer. The sample was obtained by dipping in a bottle; not by removing the scum alone. Peridinium anglicum was also present, being especially abundant in autumn.

Spirogyra porticalis was observed with laterally fused chloroplasts and $S$. varians with twin zygospores in one gametangium. The rare alga, Elakatothrix gelatinosa Wille, was found in Staddon reservoir. The infusorian Salpingaca napiformis was discovered epiphytic on the unicel-

L lular \$agerheimia genevensis. A transparent cellular sheet was formed by the encystment of Euglena viridis in great numbers.

A bibliography of twenty-nine references is included. 